\title{
Exploring School Foodservice Directors' Intentions to Implement Farm-To-School Procurement Methods Considering Food Safety Practices
}

\author{
Sandra C. Curwood, PhD, RDN (Corresponding author) \\ School Nutrition Programs Director \\ Virginia Department of Education \\ 101 North $14^{\text {th }}$ Street, Richmond, VA 23219
}

Tel: 1-805-371-2339 E-mail: sandra.curwood@doe.virginia.gov

\author{
Lakshman Rajagopal, $\mathrm{PhD}$ \\ Associate Professor in Hospitality Management, Iowa State University \\ 31MacKay Hall, 2302 Osborn Drive, Ames, Iowa \\ E-mail: 1raj@iastate.edu
}

Susan W. Arendt, PhD, RD, FAND

Professor in Hospitality Management, Associate Chair for Undergraduate Academic

Affairs, Iowa State University

9E MacKay Hall, 2302 Osborn Drive, Ames, Iowa

E-mail: sarendt@iastate.edu

Stephen W. Sapp, PhD

Professor in Sociology, Iowa State University

320 East Hall, 510 Farm House Lane, Ames, Iowa

E-mail: ssapp@iastate.edu

Received: June 5, 2018 Accepted: July 8, 2018 Published: July 24, 2018

doi:10.5296/jss.v4i1.13250 URL: https://doi.org/10.5296/jss.v4i1.13250 


\section{Abstract}

This study explored the intentions of foodservice directors' (FSD) who oversee Farm-to-School (F2S) programs to implement alternative procurement methods that better account for food safety practices. A web-based questionnaire was distributed to 864 California school FSDs with 136 (15.7\%) usable surveys returned. Findings revealed that although FSDs understand the importance of food safety training and have confidence in their ability to manage produce safety practices, they express little intention to change their procurement practices. This finding might indicate a need for more resources and supportive policies.

Keywords: farm to school, alternative procurement, food safety, school foodservice directors

\section{Introduction}

\subsection{Farm-to-School Programs}

The need for addressing food safety in alternative procurement methods such as in F2S programs has been identified by the USDA through programs, such as Produce Safety University (PSU) (USDA, FNS, 2013) and Serving Up Science: The Path to Safe Food in Schools (Serving Up Science, 2015). Previous research has not explored the potential impact of alternative procurement methods related to food safety practices as potential area of concern for the school FSD. Alternative produce procurement methods are integral to achieving objectives of local sourcing associated with F2Sprograms. While schools FSDs are responsible to maintain food safety in child nutrition programs, there is little research on how food safety practices impact school FSD's intentions to implement alternative procurement methods.

School foodservice, frequently referred to as the school nutrition program, operates under the National School Lunch Program as a federally supported meal program administered by the U. S. Department of Food and Agriculture. There are over 100,000 U.S. public and private non-profit schools participating in the program (USDA-FNS, 2013). Some schools participate in Farm-to-school (F2S) programs.

The National Farm-to-School Network describes F2S as a program that includes the practice of sourcing local agricultural products, such as produce items for schools. F2S goals include connecting agricultural products to school foodservice using alternative procurement methods, to source as directly as possible to support local and regional farmers. Experiential learning in F2S such as school gardens, farm field trips, and cooking lessons enhance the curricular experience and connections to the cafeteria and community. F2S programs aim to improve student health and communities' economic viability through local produce procurement practices (National Farm to School Network, 2015). The United States Department of Agriculture (USDA) study conducted in 2015 found that $42 \%$ of school districts, with 42,587 schools had self-identified as having F2S activities. The F2S effort has focused on connecting local farms with consistent and stable buyers. This relationship is the keystone to bringing local seasonal produce through direct marketing to support farm viability and fresh seasonal produce to school foodservice programs (Izumi, Ronstadt, Moss, \& Hamm, 2006). 


\subsubsection{Alternative Procurement Methods}

Alternative produce procurement methods as used in F2S programs consist of purchasing practices in which value along the supply chain for growers, producers, and consumer within geographic boundaries occur. Examples of these methods include grower direct, farmers market, community supported agriculture, and regional food hubs (United States Department of Agriculture, Agriculture Marketing Services, 2014). Direct marketing, used in F2S projects, has perceived benefits such as financial gain to farmers and less travel time for products resulting in fresher foods and decreased fuel used for transport (Gregoire, Arendt, \& Strohbehn, 2005). Perceived and articulated barriers to implementing F2S include cost, distribution, food safety, and legal liability (Conner et al., 2011).

\subsection{Food Safety}

School foodservice has a responsibility to uphold and promote food safety to maintain student health and well-being. According to United States Federal Drug Administration's published Food Code, school aged children are considered a population highly susceptible to foodborne illness and require additional safeguards (U.S. Food and Drug Administration, 2014). School FSDs are responsible for complying with established procurement and food safety regulations and laws from a variety of local, state, and national jurisdictions. The National School Lunch Act requires school foodservice programs to develop a comprehensive food safety management plan (USDA, Food and Nutrition Services, 2010). Food safety knowledge and training are necessary for school FSDs to implement and manage food safety and should be included in their procurement practices.

\subsection{Theory of Planned Behavior}

This study used the theory of planned behavior (TPB) (Ajzen, 1985) to explore California school FSD's behavioral, normative, and perceived control beliefs regarding food safety in F2S programs using traditional procurement and alternative procurement practices. The TPB has been used in many behavioral studies and extensively in research on hospitality management (Han \& Sheu, 2010; Jalilvand \& Samiei, 2012), local food procurement (Kang \& Rajagopal, 2014; Pilling \& Brannon, 2008; Robinson \& Smith, 2002), and food safety (Milton \& Mullan, 2012; Redmond \& Griffith, 2003; Roberts et al., 2011; York et al., 2009) to identify and predict people's behaviors based on several indicators, including attitude, subjective norms (influence of others) and perceived control of behavioral performance. The TPB proposes that behavioral performance can be predicted by the intentions to perform the behavior, the influence of others and their perceived behavioral control.

School FSDs' behavioral intentions to adopt F2S practices might be affected by their attitudes about food safety training and alternative produce procurement, perceived subjective norms (the effects that experts' and others' opinions have), and their perceived behavioral control, regarding food safety in both traditional procurement and alternative procurement. The central question posed was 'How do school FSDs' behavioral, normative and control beliefs' about food safety training impact the behavioral intentions to implement alternate procurement methods associated with F2S programs"? 


\section{Methods}

\subsection{Sample Selection}

The population was California school FSDs or designees $(n=864)$ on record with the California Department of Education (California Department of Education, 2016). Because produce safety requirements and procurement practices vary across state lines, a specific geographic region was chosen. California was selected due to the large number of F2S programs which is likely due to the long growing season and large crop variety available to school foodservices.

\subsection{Questionnaire Content}

A web-based questionnaire was used consisting of three sections and was posted in Qualtrics $^{\mathrm{TM}}$. The first section included school district characteristics. Section two questions were used to measure constructs associated with the TPB. The third section addressed FSD demographics.

In section one, school district characteristics included F2S region, number of schools, and percentage of students qualifying for free or reduced price meals, and foodservice operational questions addressed type of management, production style, and foodservice budget. Section two questions measured the constructs of attitudes, subjective norms (the degree of influence important others have on behavioral intentions) and perceived behavioral control. Attitudes, perceived behavioral control and subjective norm were measured using a 7-point Likert type scale $(1=$ strongly disagree to $7=$ strongly agree). DeVellis (2012) notes Likert-type scales are used in studies measuring beliefs and attitudes. The TPB was used to develop questions that elicit school FSDs' behavioral, normative and control beliefs' about food safety training in school foodservice and F2S programs and to assess FSDs intentions to adopt F2S procurement practices. Subjective norm is the influence that another's opinion impacts the individual to act (Ajzen, 1985). Section three is comprised of ten FSD demographic questions. These included respondent FSD personal demographics including educational background, years in school foodservice, age, and sex. Attendance at USDA's PSU as well as certification (e.g. certified food safety protection manager [CFPM]) was also asked.

\subsection{Pilot Test}

Pilot testing was conducted with a convenience sample of ten school FSDs from outside California to address questionnaire content validity and clarity, as suggested by Dillman, Smith, and Christian (2009). Based on their feedback the questionnaire was modified to read more clearly. Following this step, a pilot study was conducted in the State of Washington where there is also a strong F2S presence according to the National Farm to School Network (NFSN, 2015). Based on feedback from the pilot study $(n=30)$, modifications were made to improve clarity of some questions and to add an option respond "don't know," to the district and foodservice department demographic section. Adding the "don't know" response option provided the opportunity for respondents to move past this section to continue with the survey completion, in the circumstance of respondents not readily having access to this data. This decision potentially contributed to an increased number of respondents that may not have continued 
otherwise.

\subsection{Questionnaire Distribution}

The California Department of Education, Nutrition Services Division (CDE, NSD), distributed the hyper link to the questionnaire using their internal list serve of 864 school FSDs. Follow-up emails were sent as recommended by Dillman et al., (2009). A drawing for a \$100 gift card was offered as an incentive to increase response rate (Bosnjak \& Tuten, 2003; Deutskens, De Ruyter, Wetzels, \& Oosterveld, 2004). Institution Review Board approval was received prior to contacting potential participants.

\subsection{Data Analysis}

Statistical Package for Social Sciences (SPSS) version 22 was utilized to analyze data. Descriptive statistics were utilized to analyze the data distribution to include frequencies, means, and standard deviations, for operational and FSD demographics. Structured Equation Modeling (SEM) was selected due to its usefulness in depicting relationships between constructs (unobservable variables) and by using quantitative data to test the theoretical model, as described by Schreiber, Amaury, Stage, Barlow, and King (2006). The TPB was used as the theoretical model. Unobservable variables are measured using a series of items as depicted in Table 5. SEM analyses were conducted using LISREL 8.71

The TPB model and eight constructs are depicted in Figure 1: behavioral beliefs about food safety, normative beliefs about alternative procurement methods; control belief regarding adequacy of resources, attitudes toward food safety, subjective norm about alternative procurement methods, perceived behavioral control over alternative procurement methods, intention to implement alternative procurement methods, and implementation of alternative procurement methods (the desired behavior). The questionnaire contained groupings of questions (items) to measure each construct.

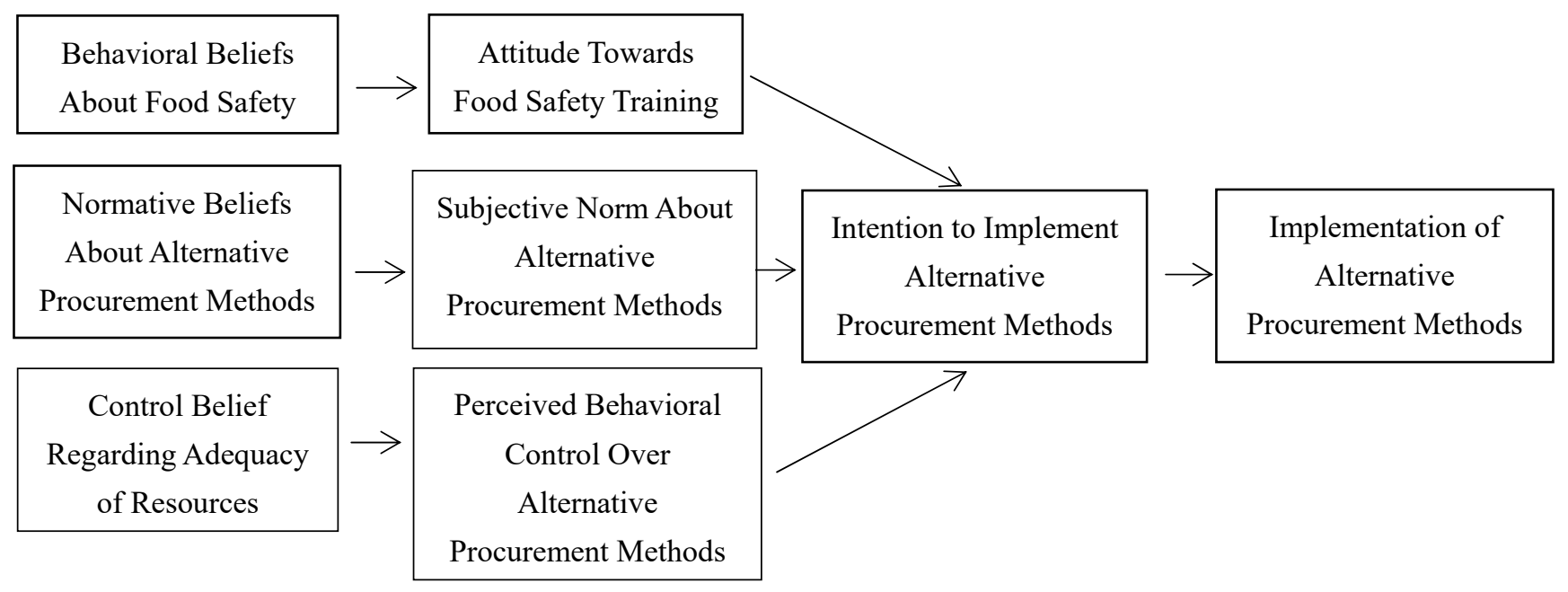

Figure 1. Based on Ajzen's Theory of Planned Behavior

Ajzen, I. (1985). The theory of planned behavior. Organizational Behavior and Human Decision Processes, 50, 179-211. Retrieved from people.umas.edu/Ajzen/tpb/diag.html 
Table 1. Constructs, Number of Items, and Item Example

\begin{tabular}{lcl}
\hline Construct & $\begin{array}{c}\text { Number of Items } \\
\text { (questions) }\end{array}$ & \multicolumn{1}{c}{ Example of Item } \\
\hline Behavioral beliefs & 8 & $\begin{array}{l}\text { I am concerned about food safety associated with alternative } \\
\text { procurement methods. } \\
\text { Most people who are important to me think I should purchase } \\
\text { produce using alternative procurement methods. }\end{array}$ \\
Normative beliefs & 6 & $\begin{array}{l}\text { I believe there is adequate training resources available for me } \\
\text { to purchase produce using alternative procurement methods. }\end{array}$ \\
Control beliefs & 9 & $\begin{array}{l}\text { I intend to use alternative procurement methods to purchase } \\
\text { produce in my operation during the next school year. }\end{array}$ \\
$\begin{array}{l}\text { Intention to implement } \\
\text { alternative procurement } \\
\text { methods }\end{array}$ & 2 & \\
\hline
\end{tabular}

Table 1 displays the construct with corresponding items use to measure and an illustrative item example. Reliability of the questionnaire was measured using Cronbach's alpha for internal consistency test for each construct: Attitude towards food safety department reputation $(\alpha=0.93)$, attitude towards food safety- management responsibility $(\alpha=0.97)$, perceived behavioral control $(\alpha=0.74)$ and subjective norm $(0.91)$, respectively. Nunnally and Bernstein (1994) cited the desired threshold for Cronbach's alpha to be 0.70 .

\section{Results and Discussion}

\subsection{FSD Demographics}

The total number of usable responses was 136, from 207 surveys that were started, representing a response rate of $15.7 \%(n=864)$. Compiled demographics reveal $84.4 \%$ of respondents were female, $45.6 \%$ were over the age of $50,39.8 \%$ had at least a bachelor's degree and $67.2 \%$ had worked in school foodservice for at least seven years, $43.3 \%$ had been in their current position for seven or more years, and majority of the participants had completed the Food Safety Protection Manager Certificate (Table 2).

Table 2. Questionnaire Respondent's Demographics ( $\mathrm{n}=125-137)$

\begin{tabular}{lcc}
\hline Category & Frequency $(n)$ & Percent $(\%)$ \\
\hline Sex & & \\
Female & 108 & 84.4 \\
$\quad$ Male & 20 & 15.6 \\
Age (years) & & \\
$18-34$ & 20 & 15.8 \\
$35-49$ & 49 & 38.6 \\
50 or older & 58 & 45.6 \\
\hline
\end{tabular}


Highest Level of Education Completed

High school

Some college

Bachelor's degree

Masters or higher

Current Job Title

Foodservice Director

Other (e.g. Assistant Director, Chef, Business Manager)

Number of Years of Work Experience in School Foodservice

$$
0 \text { to } 6
$$

7 or more

Number of Years in Current Position

0 to 6

7 or more

Type of Food Safety Certification Completed

Food Safety Protection Manager Certificate ${ }^{\text {a }}$

${ }^{a}$ Yes responses

\subsection{School District and Foodservice Department Characteristics}

Each of the California F2S regions was represented (see Table 3). The number of respondents ranged from 3.0\% indicating the Mother Lode region (located in the far north) to the southern-most portion of California, with $12.1 \%$ of respondents from the San Diego region. F2S regions were compiled into three distinct geographic categories: Northern $(n=35$, $26.5 \%)$, Central $(n=30,22.7 \%)$, and Southern $(n=67,50.8 \%)$.

Table 3. School District and Foodservice Department Characteristics $(n=125-137)$

\begin{tabular}{lcc}
\hline School Districts in California F2S Regions & Frequency (n) & Percent (\%) \\
\hline Northern & & 6.8 \\
North Valley & 9 & 7.6 \\
$\quad$ Sacramento Valley & 10 & 3.0 \\
Mother Lode & 4 & 9.1 \\
$\quad$ San Francisco Bay Area & 12 & 26.5 \\
Total Northern California & 35 & \\
\hline
\end{tabular}




\section{Macrothink}

Central

Central Valley

21

15.9

Central Coast

Total Central California

Southern

Greater Los Angeles

San Diego

South Central Coast

Total Southern California

21

50.8

School District Setting

Urban

Suburban

Rural

Student Enrollment School Year 2014-2015

2,499 or fewer students

2,500 to 9,999 students

10,000 or more students

Students Eligible for Free and Reduced Price Meals

$0-24 \%$

$25-49 \%$

$50-74 \%$

$75-100 \%$

Food Preparation Types ${ }^{\mathrm{a}}$

Speed-scratch

Mostly or All Pre-prepared

Assembly-serve

Combination/ Other

${ }^{\text {a }}$ Greater than $100 \%$ due to multiple responses

School district settings were almost equally represented, approximately one-third form each setting, rural (38.4\%), urban (28.5\%), and suburban (33.1\%). Two-thirds of districts included elementary, middle and high schools. Half of the school districts would be considered small, having less than 2,499 student enrollment, with $69.3 \%$ of districts having student eligibility for free and reduced price meals $50 \%$ and higher. The majority of foodservice operations (76.6\%) had conventional onsite cooking facilities with $62.8 \%$ using a speed-scratch 
preparation type.

Table 4 displays labor costs with ranges similar when compared to food cost ranges with the majority $(58.4 \%)$ of district's spending less than $\$ 2,000,000$ on labor. This is consistent with industry standards for operating ratios, where both food and labor percentages represent approximately equal percentages of the overall foodservice budget at about $45 \%$ each (Institute of Child Nutrition, [ICN], 2013). Annual food cost for the 2014-15 school year was under $\$ 2,000,000$ for $62.3 \%$ of participating districts, this corresponds to the majority reporting as small districts (with 2,499 or fewer students). Fresh produce costs ranged between zero and over $\$ 10,000,000$ with $70 \%$ of respondents spending less than $\$ 500,000$ annually on fresh produce. Less than $10 \%$ of FSD respondents indicated that they spent half or more of produce budget on alternate procurement, such as in F2S program. Respondents were offered the option to respond "don't know" on the annual budget information and therefore this data was not available for all respondents.

Table 4. Foodservice Department Annual Costs for School Year 2014-2015 (n=127-137)

\begin{tabular}{|c|c|c|}
\hline Category & Frequency $(n)$ & Percent $(\%)$ \\
\hline \multicolumn{3}{|l|}{ Food Cost } \\
\hline$\$ 0-\$ 499,999$ & 42 & 32.3 \\
\hline$\$ 500,000-\$ 1,999,999$ & 39 & 30.0 \\
\hline$\$ 2,000,000-\$ 9,999,999$ & 30 & 23.1 \\
\hline$\$ 10,000,000-\$ 49,999,999$ & 4 & 3.1 \\
\hline$\$ 50,000,000$ and Above & 9 & 6.9 \\
\hline Don't Know & 6 & 4.6 \\
\hline \multicolumn{3}{|l|}{ Total Fresh Produce Cost } \\
\hline$\$ 0-\$ 24,999$ & 30 & 23.1 \\
\hline$\$ 25,000-\$ 99,999$ & 31 & 23.8 \\
\hline$\$ 100,000-\$ 499,999$ & 30 & 23.1 \\
\hline$\$ 500,000-\$ 1,999,999$ & 18 & 13.8 \\
\hline$\$ 2,000,000-\$ 9,999,999$ & 2 & 1.5 \\
\hline$\$ 10,000,000$ and Above & 5 & 3.8 \\
\hline Don’t Know & 14 & 10.8 \\
\hline \multicolumn{3}{|c|}{ Alternative Procurement Produce Cost ( $\%$ of Total Produce) } \\
\hline $0 \%$ & 38 & 29.7 \\
\hline $1-24 \%$ & 67 & 52.3 \\
\hline $25-49 \%$ & 11 & 8.6 \\
\hline $50-74 \%$ & 10 & 7.8 \\
\hline $75-100 \%$ & 2 & 1.6 \\
\hline
\end{tabular}


Annual Labor Cost for 2014-15

$\$ 0-\$ 499,999$

$\$ 500,000-\$ 1,999,999$

$\$ 2,000,000-\$ 9,999,999$

$\$ 10,000,000-\$ 49,999,999$

$\$ 50,000,000$ and Above

\subsection{Theory of Planned Behavior}

The TPB model (Figure 1) uses the constructs of behavioral beliefs, normative beliefs, and control beliefs as a basis upon which attitudes towards behaviors are founded (Ajzen, 1985).

The constructs used in this study, as noted in the TPB model (Figure 1), and as listed in Table 5 , include behavioral beliefs about food safety in alternative produce purchasing, normative beliefs related to support for alternative produce purchasing, and the control belief of whether respondents believe that adequate training resources and materials are available to support food safety in alternative produce procurement. Table 5 includes means and standard deviations for each question and reliability scores for each construct and items (grouping of questions).

Table 5. Summary of Construct Measures for Behavioral Intention

\begin{tabular}{lcccc}
\hline & Construct Measure & M & SD & Reliability \\
\hline Behavioral Beliefs & & & & 0.72
\end{tabular}

.... Food safety in alternative produce purchasing

I feel confident I can manage

Believe there is no difference with traditional

Has more concerns than traditional procurement

I am concerned about
$5.39 \quad 1.54$

$3.83 \quad 1.94$

$3.62 \quad 1.83$

$3.48 \quad 1.83$

\section{Normative Beliefs}

Purchasing produce from alternative sources is supported by ...

Professionals whose opinion I value

California Department of Education

$5.40 \quad 1.54$

Most people important to me

$4.35 \quad 1.76$

Other school FSDs

$4.33 \quad 1.66$


Adequate training resources are available for me

$\begin{array}{ll}4.36 & 1.68\end{array}$

Attitude Related to Department Reputation

Offering food safety training to my employees will ...

Increase employees' awareness of food safety

$6.59 \quad 0.98$

Ensure safe food

$\begin{array}{ll}6.56 & 0.97\end{array}$

Help maintain the department reputation

$6.49 \quad 1.07$

Decrease the likelihood of lawsuits

$6.28 \quad 1.20$

Attitude Related to Management Responsibility

0.84

Keep my customers satisfied

$5.92 \quad 1.51$

Increase employee satisfaction

$5.83 \quad 1.37$

Keep my supervisor satisfied

$5.70 \quad 1.67$

Reduce food cost

$5.39 \quad 1.76$

Subjective Norm about Food Safety Training

Likelihood others think you should offer food safety training ...

Health Inspector

$6.59 \quad 1.18$

Immediate supervisor

$6.25 \quad 1.36$

District superintendent

$6.20 \quad 1.26$

Customers (students, parents, faculty)

$6.15 \quad 1.19$

Board of Education

$6.07 \quad 1.37$

Long-term employees

$5.87 \quad 1.48$

Short-term employees

$5.69 \quad 1.47$

Vendors

$5.30 \quad 1.69$

Perceived Behavioral Control Regarding Food Safety Training

What makes it difficult to provide food safety training ...

Employee scheduling availability

Time commitment for training

Manager's time

Financial resources 
Lack of off-site opportunities

Lack of targeted materials

Employees don't practice what they learn

$3.50 \quad 1.94$

Subjective Norm Regarding Alternative Produce Purchasing

Purchasing produce from alternative sources is supported by ...

Parents

Board of Education

School district superintendents

School chief business officials

Students

.... Purchase produce directly in the next school year.

I will try to

$5.44 \quad 1.74$

It's my choice

$5.31 \quad 1.94$

I plan on it

$5.14 \quad 1.86$

I am able to

Behavioral Intention to Use Alternative Produce Procurement

Likelihood to increase alternative produce purchasing ...

I want to during the next school year

I do not expect to in the next school year (reversed)

I intend to in the next school year

$4.93 \quad 1.96$

\subsection{Beliefs- Behavioral, Normative, and Control}

Behavioral beliefs related to food safety in alternative produce procurement were measured with two items. The highest level of agreement was with the statement "I feel confident I can manage food safety in alternative produce procurement $(\mathrm{M}=5.39, \mathrm{SD}=1.54)$, with the lowest level of agreement with the statement "I am concerned about produce safety in alterative produce procurement" $(\mathrm{M}=3.48, \mathrm{SD}=1.83)$.

To address the construct of normative beliefs related to alternative produce procurement questions included "purchasing produce for an alternative source is supported by ..." with a list of responses that includes professionals and experts. Those items with the highest level of agreement for normative beliefs among respondent FSDs included "professional whose 
opinion I value" $(\mathrm{M}=5.65, \mathrm{SD}=1.48)$, with the lowest level of agreement for "other school FSDs" $(\mathrm{M}=4.33, \mathrm{SD}=1.66)$.

Control beliefs were measured by asking respondent FSDs if they believed there were adequate training resources and materials available to purchase produce safely using alternative procurement methods results supporting this were modest $(\mathrm{M}=4.36, \mathrm{SD}=1.68)$.

\subsection{Attitudes towards Food Safety Training}

The questionnaire measured three constructs related to food safety training and these were: attitude, subjective norm, and perceived behavioral control. Respondent FSD's were asked to rate their level of agreement with a list of items related to food safety training.

Attitudes toward food safety training were grouped into two categories: attitude that food safety training is important to the foodservice department reputation and FSDs' management responsibility. Increasing employees' awareness of food safety had a high level of agreement $(\mathrm{M}=6.59, \mathrm{SD}=0.98$; using a 7-point Likert-type scale) among respondents for maintaining department reputation. While positive attitudes toward keeping customers satisfied $(M=5.92$, $\mathrm{SD}=1.51$ ) were noted for measures that were used to analyze the strength of respondent FSD's attitudes towards food safety training.

Respondent FSDs indicated the highest level of agreement was with the health inspector (M $=6.59, \mathrm{SD}=1.18$ ) for those experts and other professionals having the most influence. Perceived behavior control, looking at what makes it difficult to provide food safety training and the FSD respondents' ability to manage this, was most often related to employee scheduling availability $(\mathrm{M}=5.34, \mathrm{SD}=1.77)$ and time commitment for training $(\mathrm{M}=5.08$, $\mathrm{SD}=1.83)$.

\subsection{Subjective Norm}

The same Likert-type scale was used to assess respondent FSD's level of agreement related to using alternative procurement methods to purchase produce. Purchasing produce from alternative methods was supported by "parents" $(\mathrm{M}=4.58, \mathrm{SD}=1.44)$ having the most level of agreement by respondents, yet "students" $(\mathrm{M}=3.71, \mathrm{SD}=1.61)$ had the least. "The measure of perceived behavioral control over alternative produce purchasing that respondent FSDs most strongly agreed with was their willingness to try to purchase directly using alternative procurement methods $(\mathrm{M}=5.44, \mathrm{SD}=1.74)$ with their actual "ability to procure directly" has the least agreement $(\mathrm{M}=4.92, \mathrm{SD}=1.99)$.

Intention was measured by asking three questions about their likelihood to use alternative produce procurement. Respondents were found to have the highest level of agreement with the statement "I want to increase alternative produce procurement during the next school year" $(\mathrm{M}=5.16, \mathrm{SD}=1.74)$ and the lowest level with "I intend to in the next year" $(\mathrm{M}=4.93$, $\mathrm{SD}=1.96)$, possibly an indication that action would not actually be taken.

\subsection{Intentions to implement}

A series of Structured Equation Modeling (SEM) analyses were used to test the adequacy of 


\section{Macrothink Institute ${ }^{\mathrm{TM}}$}

measures to explain the school FSD's intentions to implement alternative procurement methods associated with F2S programs. Table 6 also displays a covariance matrix depicting how data varies between the eight constructs based on 137 observations. In the covariance matrix all the values are positive indicating a positive covariance between each pair. For example, as the level of agreement related to attitudes towards food safety training increases, so does the intention to implement alternative procurement methods to procure produce. However, because the results are small in effect, this finding would suggest the relationship is not linear and therefore cannot be used to predict behavioral change.

Table 6. Structural Equation Modeling Evaluation of Measures for Covariance Matrix, Maximum Likelihood Estimates and $\mathrm{R}^{2}$ Values and Standardized Regression Coefficients $(\beta)$ for Impact on Intention

Covariance Matrix Measures for Impact on Intention

\begin{tabular}{|l|l|l|l|l|l|l|l|l|}
\hline & Intention & Dept $^{\mathrm{a}}$ & $\begin{array}{c}\text { Mgmt } \\
\mathrm{b}\end{array}$ & $\mathrm{SN}$ & $\mathrm{PBC}$ & $\begin{array}{c}\text { Behavioral } \\
\text { Beliefs }\end{array}$ & $\begin{array}{c}\text { Normative } \\
\text { Beliefs }\end{array}$ & $\begin{array}{c}\text { Control } \\
\text { Beliefs }\end{array}$ \\
\hline Intention & 3.084 & & & & & & & \\
\hline $\begin{array}{l}\text { Department } \\
\text { Reputation }\end{array}$ & 0.368 & 0.940 & & & & & & \\
\hline $\begin{array}{l}\text { Management } \\
\text { Responsibility }\end{array}$ & 0.151 & 0.861 & 1.561 & & & & & \\
\hline $\begin{array}{l}\text { Subjective } \\
\text { Norms (SN) }\end{array}$ & 0.664 & 0.401 & 0.446 & 1.905 & & & \\
\hline $\begin{array}{l}\text { Perceived } \\
\text { Behavior } \\
\text { Control (PBC) }\end{array}$ & 1.732 & 0.446 & 0.251 & 0.447 & 2.387 & & \\
\hline $\begin{array}{l}\text { Behavioral } \\
\text { Beliefs }\end{array}$ & 0.233 & 0.069 & 0.073 & 0.011 & 0.150 & 0.782 & & \\
\hline $\begin{array}{l}\text { Normative } \\
\text { Beliefs }\end{array}$ & 1.135 & 0.385 & 0.377 & 0.939 & 0.732 & 0.107 & 1.602 & \\
\hline $\begin{array}{l}\text { Control } \\
\text { Beliefs }\end{array}$
\end{tabular}




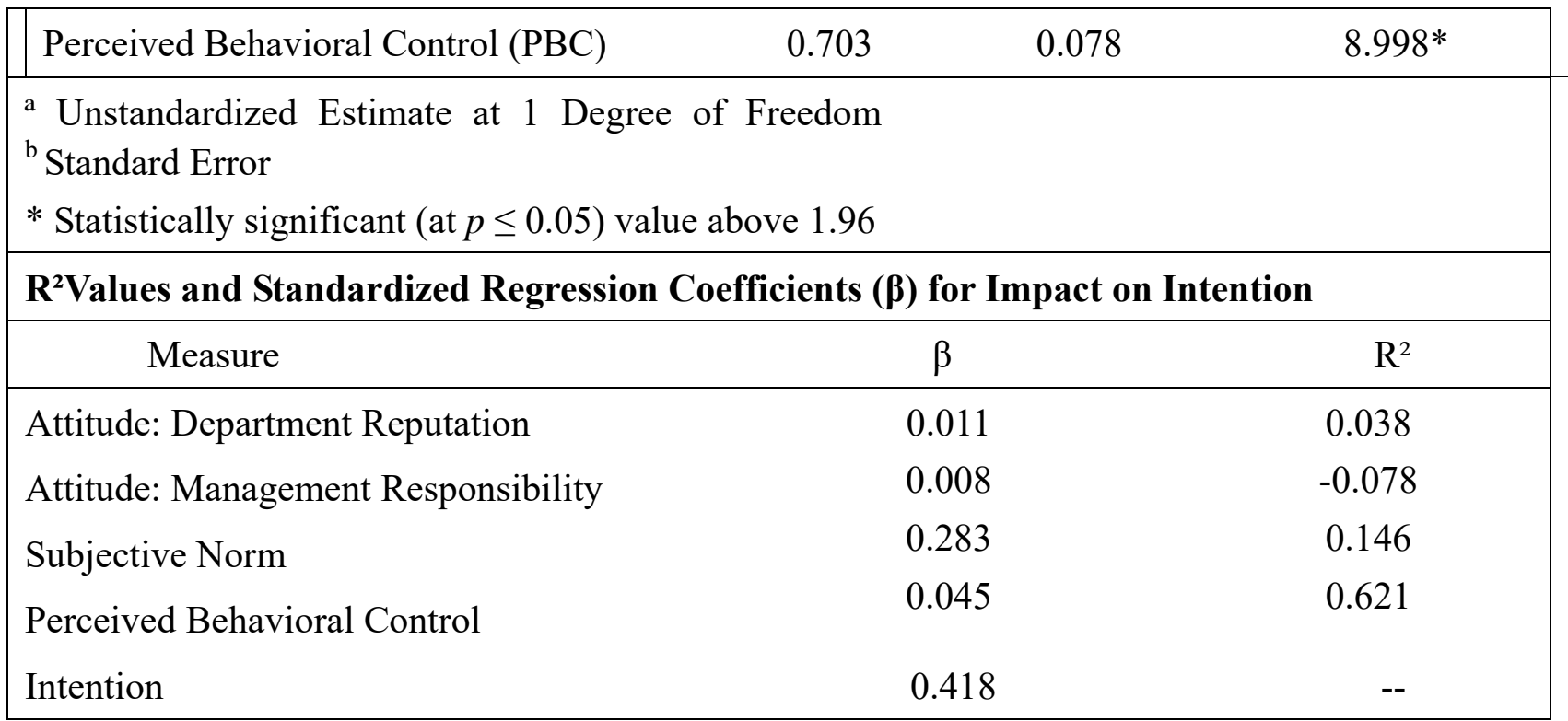

Maximum likelihood estimates, using $t$-ratios, calculated using the unstandardized estimate at 1 degree of freedom and standard error, along with beta regression coefficients, are displayed in Table 6. The maximum likelihood for the pathway from attitude about food safety department reputation $(t-$ ratio $=.557, \beta=0.038)$ and attitude about food safety management responsibility ( $t$ ratio $=0.557, \beta=0.078$ ), to intention are not statistically significant (at $p \leq$ 0.05 ) as a predictor of school FSD's intention to purchase produce using an alternative procurement method.

When examining the pathway from subjective norm ( $t$-ratio $=2.090, \beta=0.146)$ to intention to implement alternative procurement methods, it is statistically significant (at $p \leq 0.05$ ) and suggests the influence of others (experts and professionals and those noted as important to respondents) positively relates to the intention to implement F2S. Additionally, perceived behavioral control ( $t$-ratio $=8.998, \beta=0.621$ ) is statistically significant (at $p \leq 0.05$ ) and indicates that perceived behavioral control positively predicts intention to implement alternative procurement methods associated with F2S.

R-Square values for each of the measures (Table 6), attitude towards food safety training related to department reputation $\left(\mathrm{r}^{2}=.011\right)$, attitude about food safety related to management responsibility $\left(\mathrm{r}^{2}=.008\right)$, subjective norm $\left(\mathrm{r}^{2}=.283\right)$, and perceived behavioral control $\left(\mathrm{r}^{2}\right.$ $=.045)$, were small, also indicating a weak linear relationship with intention to purchase produce using alternative procurement methods. Therefore, the hypothesis associated with the TPB that behavioral beliefs about food safety could not be substantiated and did not predict school FSD's intention to use alternative procurement methods. The variance in intention $\left(\mathrm{r}^{2}\right.$ $=0.418$ ) is instead explained $41.8 \%$ of the time by perceived behavioral control.

These findings are further supported by additional analyses. To evaluate the overall goodness of fit, to determine how well the observed data matched expected data from the model, Chi-square and root mean square error of approximation (RMSEA) were used. The Chi-square value (154.894) further demonstrates a poor model fit. Additionally, RMSEA value $(0.207)$ is outside the acceptable range. Less than 0.08 indicates a good model fit as 
noted by MacCallum, Browne, and Sugawara (1996).

\section{Conclusion and Applications}

This study explored school FSD's intentions to implement F2S procurement methods considering food safety practices using the TPB (Ajzen, 1985). This study may have been limited by the low response rate of $15.7 \%$ (136 from 864) potential respondents yielding 136 usable surveys. This outcome could be reflective of over-surveying of California school FSDs or possibly that the survey was sent out too close to school districts Spring breaks. Considering the magnitude of changes in school nutrition programs in recent years (such as implementation of the Healthy, Hunger Free Kids Act, 2010), FSDs may not have prioritized completing the questionnaire.

The results may not be generalizable as laws and regulations vary across state lines and jurisdictions. Support, resources and training, are more robust in some states than others, and this may affect the generalizations that could be drawn from this study.

Findings indicate that respondent FSDs have confidence in their ability to manage food safety when using alternative produce procurement methods and are ambivalent about any differences with produce safety in alternative produce procurement. This finding suggests FSDs had the capacity to manage food safety independent of the procurement method used, either through conventional or alternative procurement methods.

High mean scores were noted for normative beliefs related to the influence of professionals whose opinion the FSD valued; however, this influence did not extend to their peers (other FSDs). This finding was inconsistent with other studies. Chen, Arendt, and Shelley (2010) noted a strong relationship between the influences of peers on sustainable practices among college foodservice directors. Results were not conclusive for control beliefs, measured by asking respondent FSD's if they believed there were adequate training resources and materials available to purchase produce safely using alternative procurement methods.

Findings showed that FSD's attitude regarding food safety training indicated that increasing employee's awareness of food safety was important in maintaining the department reputation, highlighting the importance of food safety training for employees. While keeping customers satisfied was positively related to the FSD's management responsibility. Respondent FSD's indicated that the health inspector had the strongest influence of the subjective norm measures with regards to the importance of offering food safety training. At least two health inspections are required annually in each cafeteria (USDA, FNS, 2014) and the results are frequently posted on the internet, emphasizing the impact of the role of the inspector. Employee scheduling availability was noted as making it difficult for the FSD to provide food safety training as well as finding the time to train.

Parents were noted as having the greatest influence on the school FSD's intention to use alternative produce procurement methods, while students were found to have the least. Students are generally considered to be the primary customer of the school foodservice operation; however, this finding would indicate the importance of parents' influence regarding student meal participation. Stokes, Arendt, and Strohbehn (2014), in a study about 
foodservice employee's perceptions about F2S, found that school foodservice employee's perceived that getting support from parents and students were equally important, in implementing F2S programs $(\mathrm{n}=199-211)$. In another study, customers were noted as important to influencing decisions to implement sustainable practices, such as local purchasing, in colleges and university foodservice (Chen, Arendt, \& Gregoire, 2011). School FSDs indicated a strong willingness to try to procure using alternative methods, yet their actual ability to procure alternatively was weaker, possibly indicating a lack of capacity to change their process. FSDs indicated their desire to increase alternative methods usage; however, their intention was much lower. This could be interpreted that action would not be undertaken, despite their indicated desire.

The lack of a linear relationship in the SEM pathways indicates that while the TPB model did not perform well, as evidenced by the R-squared values, the measurements are valid and reliable for this study. The R-squared values indicated that attitudes and subjective norm explained little of the variance in intentions to use alternative procurement methods. However, the explained variance in intentions $\left(\mathrm{r}^{2}=.418\right)$ is related to perceived behavioral control over alternative procurement methods, in so much as actions are taken based on administrative directives. The modest results are possibly more reflective of school FSD's lack of decision making authority at the mid-level management position. Therefore, their behavioral, normative, and control beliefs are less contributory to the ability to implement alternative produce procurement methods as they are not the ultimate decision makers.

The TPB (Ajzen, 1985) did not perform well and did not explain determinants of intention. Therefore, conclusions based on the TPB could not be supported. The TPB model assumed that school FSD's had control or perceived control, however the relationship between control beliefs and perceived behavioral control did not support this assumption and therefore the theory was interrupted. Future studies could include additional theory to address what is structurally inhibiting the relationship, for example inclusion of risk avoidance component; such as risk homeostasis theory (Wilde, 1982).

These results would suggest if implementing alternative produce procurement methods is desirous, it would likely have to take place at a policy or mandate level. Additionally, giving more decision-making ability at the school FSD level would support use of alternative produce procurement methods. Identifying what is potentially flawed in the existing system, in that these practices could be included in the Healthy, Hunger Free Kids Act, which authorizes funding for federal school meals programs or as part of reauthorization of the Child Nutrition Act a United State federal law authorizing the National School Lunch Program. The results also demonstrate a need for additional research to determine if findings are representative of other geographic regions across the United States.

\section{References}

Ajzen, I. (1985). From intention to actions: A theory of planned behavior. In J. Kuhl, \& J. Beckmann (Eds.), Action Control: From cognition to behavior (pp. 11-39). https://doi.org/10.1007/978-3-642-69746-3_2 
Ajzen, I., \& Fishbein, M. (1980). Understanding attitudes and predicting social behavior. Englewood Cliffs, NJ; Prentice-Hall. https://doi.org/9780139364358

Bosnjak, M., \& Tuten, T. L. (2003). Prepaid and promised incentives in web surveys: An experiment. Social Science Computer Review, 21(2), 208-217. https://doi.org/10.1177/0894439303021002006

California Department of Education (2016). Nutrition Services Division. National School Lunch program. Retrieved from http://www.cde.gov/ls/nu/sn/nslp.asp

Chen, C. J. R., Arendt, S. W., \& Gregoire, M. (2010). What sustainable practices exist in college and university dining services? Journal of Foodservice Management \& Education, 4(1), 5-10. Retrieved from https://lib.dr.iastate.edu/aeshm_pubs/43/

Chen, C. R. Gregoire, M. B., Arendt, S., \& Shelley, M. C. (2011). College and university dining services administrators' intention to adopt sustainable practices: Results from US institutions. International Journal of Sustainability in Higher Education, 12(2), 145-162. https://doi.org/10.1108/14676371111118200

Conner, D. S., King, B., Koliba, C., Kolodinsky, J., \& Trubek, A. (2011). Mapping farm-to-school networks: Implications for research and practice. Journal of Hunger \& Environmental Nutrition, 6(2), 133-152. https://doi.org/10.1080/19320248.2011.576206

Deutskens, E., De Ruyter, K., Wetzels, M., \& Oosterveld, P. (2004). Response rate and response quality of Internet-based surveys: An experimental study. Marketing Letters, 15(1), 21-36. http://doi.org/10.1023/B:MARK.0000021968.86465.00

DeVellis, R. F. (2012). Scale development: Theory and applications. Los Angeles, CA: Sage publications.

Dillman, D. A., Smyth, J. D., \& Christian, L. M. (2009). Internet, mail, and mixed-mode surveys: The tailored design method. Hoboken, NJ: Wiley.

Gregoire, M. B., Arendt, S. W., \& Strohbehn, C. H. (2005). Iowa producers' perceived benefits and obstacles in marketing to local restaurants and institutional foodservice operations. Journal of Extension, 43. Retrieved from https://lib.dr.iastate.edu/aeshm_pubs/20/

Han, H., Hsu, L. T. J., \& Sheu, C. (2010). Application of the theory of planned behavior to green hotel choice: Testing the effect of environmental friendly activities. Tourism Management, 31(3), 325-334. https://doi.org/10.1016/j.tourman.2009.03.013

Institute of Child Nutrition [ICN] (2013). Financial analysis and program evaluation. Retrieved from http://www.nfsmi.org/documentlibraryfiles/PDF/20080225030902.pdf

Izumi, B. T., Rostant, O. S., Moss, M. J., \& Hamm, M. W. (2006). Results from the 2004 Michigan Farm-to-School Survey. The Journal of School Health, 76(5), 169-174. https://doi.org/10.1111/j.1746-1561.2006.00090.x

Jalilvand, M. R., \& Samiei, N. (2012). The impact of electronic word of mouth on a tourism destination choice: Testing the theory of planned behavior (TPB). Internet Research: 
Electronic Networking Applications and Policy, 22(5), 591-612. https://doi.org/10.1108/10662241211271563

Kang, S., \& Rajagopal, L. (2014). Perceptions of benefits and challenges of purchasing local foods among hotel industry decision makers. Journal of Foodservice Business Research, 17(4), 301-322. https://doi.org/10.1080/15378020.2014.945889

Kuder, G. F., \& Richardson, M. W. (1937). The theory of the estimation of test reliability. Psychometrika, 2(3), 151-160. https://doi.org/10.1007/BF02288391

MacCallum, R. C., Browne, M. W., \& Sugawara, H. M. (1996). Power analysis and determination of sample size for covariance structure modeling. Psychological methods, 1(2), 130. https://doi.org/10.1111/j.1746-1561.2006.00090.x

Milton, A. C., \& Mullan, B. A. (2012). An application of the theory of planned behavior: A randomized controlled food safety pilot intervention for young adults. Health Psychology, 31(2), 250. https://doi.org/10.1037/a0025852

National Farm-to-School Network. (2015). Accessed on May 31, 2015. Retrieved from: http://www.farmtoschool.org/

Nunnally, J. C., \& Bernstein, I. H. (1994). Psychometric Theory (3rd ed.). New York, NY: McGraw-Hill. https://doi.org/10.1177/014662169501900308

Pilling, V. K., Brannon, L. a, Shanklin, C. W., Howells, A. D., \& Roberts, K. R. (2008). Identifying specific beliefs to target to improve restaurant employees' intentions for performing three important food safety behaviors. Journal of the American Dietetic Association, 108(6), 991-7. https://doi.org/10.1016/j.jada.2008.03.014

Redmond, E. C., \& Griffith, C. J. (2003). A comparison and evaluation of research methods used in consumer food safety studies. International Journal of Consumer Studies, 27(1), 17-33. https://doi.org/10.1046/j.1470-6431.2003.00283.x

Roberts, K. R., \& Barrett, B. B. (2011). Restaurant managers' beliefs about food safety training: An application of the theory of planned behavior. Journal of Foodservice Business Research, 14(3), 206-225. https://doi.org/10.1080/15378020.2011.594379

Robinson, R., \& Smith, C. (2002). Psychosocial and demographic variables associated with consumer intention to purchase sustainably produced foods as defined by the Midwest Food Alliance. Journal of Nutrition Education and Behavior, 34(6), 316-325. https://doi.org/10.1016/S1499-4046(06)60114-0

Schreiber, J., Amaury, N., Stage, F. K., Barlow, E. A., \& King, J. (2006). Reporting structural equation modeling and confirmatory factor analysis results: A review. The Journal of Education Research, 99(6), 323-337. https://doi.org/10.3200/JOER.99.6.323-338

Stokes, N., Arendt, S. W., \& Strohbehn, C. H. (2014). What sustainable practices exist in college and university dining services? Journal of Foodservice Management \& Education, 9(1), 1-11. Retrieved from https://lib.dr.iastate.edu/aeshm_pubs/43 


\section{Macrothink

U.S. Department of Agriculture, Agricultural Marketing Service. (2014). Local food promotion program. Retrieved from http://www.ams.usda.gov/services/grants/lfpp.

U.S. Department of Agriculture, Food and Nutrition Services. (2016). Farm to school census. Retrieved from https://farmtoschoolcensus.fns.usda.gov/

U.S. Department of Agriculture, Food and Nutrition Services. (2010). Food safety WIC reauthorization Act of 2004.2 Retrieved from https://www.fns.usda.gov/food-safety-wic-reauthorization-act-2004

U.S. Department of Agriculture, Food and Nutrition Services. (2014). Healthy hunger free kids act. Retrieved from https://www.fns.usda.gov/school-meals/healthy-hunger-free-kids-act

U.S. Department of Agriculture, Food and Nutrition Services. (2013). Produce safety university. Retrieved from https://www.fns.usda.gov/food-safety/produce-safety-university

U. S. Food and Drug Administration. (2014). Foodborne illness and contaminants. Retrieved from https://www.fda.gov/Food/FoodborneIllnessContaminants/default.htm

Wilde, G. J. S. (1982), Critical Issues in Risk Homeostasis Theory. Risk Analysis, 2, 249-258. https://doi.org/10.1111/j.1539-6924.1982.tb01389.x

York, V. K., Brannon, L A., Shanklin, C. W., Roberts, K. R., Howells, A. D., \& Barrett, E. B. (2009). Foodservice employees benefit from interventions targeting barriers to food safety. Journal of the American Dietetic Association, 109(9), 1576-81. https://doi.org/10.1016/j.jada.2009.06.370

\section{Copyright Disclaimer}

Copyright for this article is retained by the author(s), with first publication rights granted to the journal.

This is an open-access article distributed under the terms and conditions of the Creative Commons Attribution license (http://creativecommons.org/licenses/by/4.0/) 